\title{
COMPLIANCE WITH THE PRINCIPLE OF ENFORCEMENT FROM OFFICE OF THE ADMINISTRATIVE ACT ACCORDING TO THE DISPOSITIONS OF THE FUTURE CODE OF ADMINISTRATIVE PROCEDURE
}

\author{
A. M. Popescu
}

\section{Agata Mihaela Popescu}

Facutly of Juridical and Administrative Sciences

"Dimitrie Cantemir" Christian University, Bucharest, Romania

* Correspondence: Agata Mihaela Popescu, 129 Şoseaua Olteniei St., Sector 4, Bucharest, Romania

E-mail: av.agata@yahoo.com

\section{Abstract}

Lately, the national juridical order of every country has been influenced by the supranational juridical systems due to the globalization phenomena, without it being possible to deny the interdependence of internal legislations, since the state, as contracting party of various international conventions, has several obligations to comply with, including obligations to adopt various laws subsequent to the agreements it signed.

Due to the transformations that occurred in all areas of activity of human society, we can note that we are assisting a process of convergence between the administrative law of EU Member States and the European administrative law, process that is in a continuous development.

As Romania assumed the EU acquis, it has the obligation to implement in its national legislation the general administrative procedure principles shaped at this level, principles among which one can also find the principle of enforcement from office of the administrative act.

Keywords: codification, administrative act, enforceable act, administrative procedure

\section{Introduction}

From a reserved attitude of most authors in the interwar period, mostly due to the diversity, but also the dynamics of the legislation in this field, the postwar period was characterized by a position favorable to codifying the administrative procedures, although the law-making process did not comply.

As far as the efficiency and the utility of adopting an Administrative Code is concerned, even before 1989 it was considered that such a normative act would contribute to clarifying the administrative juridical system, allowing a systematization of the legislation in the field of state administration; these considerations still stand today, as long as we replace the concept of state administration with that of public administration. After 1990, the theory of the necessity of codifying administrative law rules reappeared, starting from the premises that a modern, civilized public administration, in a democratic and social state of law must be a transparent one, characterized by clear rules that are as much as possible, uniform and accessible to all. ${ }^{1}$

The administrative codification is, alongside the other codifications, the quintessence of the systematization of law, imposing itself in the process of reforming the public

\footnotetext{
${ }^{1}$ Dana Apostol Tofan, Domnica Focsaneanu, Catalina Suta, Proiectul Codului adminsitrativ al Romaniei, Curierul Judiciar no. 2/21.07.2001.
} 
administration, of overcoming the obstacles it currently faces. The administrative codification would bring multiple advantages that would consist, among others, in simplifying and correlating the legislation in the field, reducing the immense number of existing regulations, creating a general reference legal framework that would, in link with the code, eliminate parallelisms, contradictions and incoherencies in the legislation and also certain deficiencies stemming from not motivated acts, parties not being subpoenaed etc. ${ }^{2}$

Moreover, the future Code of Administrative Procedure should ensure full harmony between the internal legislation and the EU one. A compared study of the level of integration of EU legislation in Member States would be truly useful for the future code, so that it includes unequivocal administrative procedural norms that determine a uniform application according to the existing EU legislation.

Also, alongside the three different juridical orders (norms from the national legislation, the EU legislation and the European Convention of Human Rights), one can note a real normative competition, on the creator appanage of the jurisprudence, in shaping and developing administrative procedural norms.

Precisely because of that, as a consequence of signing the treaty to become member of the European Union, Romania is being confronted with the problem of integrating the European structures, and to accomplish this objective, it has to put sustained effort into improving its constitutional, legislative and institutional systems; the role of the Romanian legislator is to unify the norms by codifying and consolidating them, as well as to harmonize the legal regulations.

If the first step in preparing the constitutional mechanisms for the implementation of the EU law has been made by revising the fundamental law, another step that needs to be taken is codifying the administrative procedure; this is bound to start from a thorough knowledge of social needs and a deep understanding of the link between procedure and substantial law.

In our opinion, an improvement in the judicial protection of citizens and a good administration could be achieved this way, giving any person the possibility to benefit from an impartial, equal treatment from public institutions.

The illustration of these arguments consists in the fact that at present, frequently, during the same law suit, the judge is called to apply rules of the EU law, of the national law as well as regulations of independent administrative authorities, situation that can lead to conflicts between them, but mostly to an practice lacking uniformity.

One cannot ignore or minimize the fact that the ambiguity and incoherence of the legislation leaves a great freedom of manoeuvre to the public administration in adopting administrative acts, but also to the judge in administrative cases when analyzing the legality of the act.

We consider that the codifying activity would be a remedy both against inflation and legislative disorder, problem that should represent a constant preoccupation of all political factors and of public authorities with attributions on the field.

A place of its own in the future Code for Administrative Procedure will have, alongside other principles, the principle of enforcement from office of the administrative act, starting from the reality that currently, its existence is unanimously acknowledged in Romanian doctrine and that it is included in most legislations of EU states.

The decisive arguments leading to keeping the idea that the unilateral administrative act is a writ of execution as a priority of the future Administrative Procedure Code, consist of the fact that it is a constant principle in the Romanian administrative law doctrine, as well as

\footnotetext{
${ }^{2}$ Ioan Alexandru, Un punct de vedere în conturarea unei concep $\square$ ii privind elaborarea Codului Administrativ, Revista română de drept no. 9/1976.
} 
in that of other EU states, but also because the administrative procedure laws in the latter explicitly mention it.

It is highly important that the regulation of the forced execution of administrative acts can be found in a separate section of the future Administrative Procedure Code (in the project for a Code, one could find the respective dispositions at art. 128 - 136), eliminating the possibility of regulating and adopting a separate special law. This is way the following essential aspects should be taken into account:

- the listing of the principle of proportionate execution in the future Administrative Procedure Code should consider that the measures taken by public authorities that affect the rights or reasonable interests of individuals should be necessary and proportionate to the goal that is followed;

- the forced execution action should be defined and the delay by which it can be done should be established;

- the fact that the forced execution can be done at the request of the administrative authority that issued the act that constitutes writ of execution or at that of the creditor of the obligation to execute should be specified;

- the conditions that need to be accomplished for the forced execution should be mentioned, as follows:

a) the existence of the writ of execution in writing;

b) the proof of having communicated the interested person on the administrative act that constitutes the writ of execution;

c) the administrative authority competent to note the rejection to proceed to voluntary execution of the debtor, as well as the lack of an objective justification in this regard;

d) there should be no exception from the rule of immediate execution of the administrative act;

- the administrative sanctions that could be applied by administrative authorities should be established (the principle of legitimacy of the administrative sanction);

- the principle of non-retroactivity of sanctions should be included.

One shouldn't forget that the procedure of applying administrative sanctions needs to comply with the guarantees assured by art. 6 of the European Convention of Human Rights. We are thus considering that the following need to be specified, according to the framework established by the Convention:

- the principle of necessity, as well as the principle of proportionality between the administrative sanction applied and the offense committed by the debtor of the obligation to execute;

- the adversarial principle that includes the right to defense, the possibility of hearing the party, his right to present the reasons for which he didn't voluntarily execute the administrative act, the motivation of the corresponding administrative sanction applied, the right of the party to challenge the legality of the administrative sanction applied and to demand it's suspension until the appeal is solved;

- the possibility of engaging the material responsibility of the administrative authority that is guilty of having illegally forcedly executed the administrative act. 
From another point of view, we believe that mentioning in the project for an Administrative Procedure Code the procedure for appealing against the execution of an administrative act directly done at the public authority or the hierarchically superior one is assimilated to the administrative appeal before going to the administrative court.

In order to ensure a uniform and easy implementation by public authorities of the legal solutions aimed to remedy the malfunctions of the legal framework, it is necessary to foresee the possibility, for the party obliged to execute an administrative act, to appeal the execution and to be aware of all procedural aspects so as to not leave room for interpretation.

\section{Conclusions}

- As the Romanian doctrine in the field of administration constantly emphasized, the enforcement from office of administrative acts, it is more than necessary to stipulate this juridical reality as a general principle in a future Administrative Procedure Code. Moreover, this essential rule is present in certain normative acts with a departmental character, just like the disposition that the administrative act is a writ of execution. Emphasizing the fact that the administrative act does no longer need to be invested with enforcement formula in a future law that regulates the non-contentious administrative procedure seems obvious.

- $\quad$ As it was underlined, the presumption of legality of an administrative act is the basis of the principle of its writ of execution. As a logical consequence, the legislator can take into account this presumption so as to regulate it accordingly.

- As far as Romania is concerned, there is a lot of effort that still needs to be put in the normative, administrative and jurisprudential field as far as the implementation of the rules imposed by the European Convention of Human Rights is concerned or EU laws. Of course, the existing national non-contentious procedure is also delayed compared to European standards. One thing is certain: the juridical effects of administrative acts and the procedure of their execution needs to be submitted to strict rules from the moment they enter into force till its effects cease.

\section{Bibliography}

Rozalia-Ana Lazăr, Legalitatea actului administrativ. Drept românesc şi drept comparat, All Beck Publishing, Bucharest, 2004;

Corleliu Liviu Popescu, Autonomia locală şi integrarea europeană, All Beck Publishing, Bucharest, 1999; Bucharest 2002;

Dana Apostol Tofan, Dominica Focsaneanu, Catalina Suta, Proiectul Codului administrativ al României, Curierul Judiciar no. 2/21.07.2001;

André de Laubadère, Yves Gaudement, Traité de Droit Administratif, vol. 1, $16^{\text {th }}$ edition, L.G.D.J., E.J.A., Paris, 2001;

Ioan Alexandru, Un punct de vedere în conturarea unei concepții privind elaborarea Codului Administrativ, in "Revista română de drept" Review, no. 9/1976. 